\title{
Nutrition and inborn errors of metabolism: challenges in Phenylketonuria
}

\author{
Elvira Verduci , Valentina Rovelli, Francesca Moretti, Juri Zuvadelli, Elisabetta Salvatici \\ From 70th Congress of the Italian Society of Pediatrics, Joint National Meeting SIP, SICuPP, SITIP \\ Palermo, Italy. 11-14 June 2014
}

Phenylketonuria (PKU) is caused by the deficiency of the phenylalanine hydroxylase enzyme, which converts phenylalanine (Phe) to tyrosine. If left untreated from birth, this deficiency results in high levels of Phe in the blood, neurotoxic to the brain [1].The restriction of dietary Phe represents the mainstain of PKU management. PKU diet is mainly made up by variable amounts of vegetables and fruits (poor in Phe natural foods), minimal amounts of animal products (usually milk), low-protein foods (lowprotein bread and pasta) and Phe-free protein substitutes, which provide mainly essential aminoacid and micronutrients, to reach the required amount of daily protein, minerals and vitamins [2,3]. This type of dietary regimen provide lower saturated and polyunsaturated fat, cholesterol as well as higher carbohydrates intake than healthy pediatric population. The PKU diet follows the norms of the so called "prudent" diet for the prevention of cardiovascular disorders. In particular saturated fats may be less than $7 \%$ and polyunsaturated higher than $5 \%$ total energy with a supply less than $50 \mathrm{mg}$ cholesterol per day [2]. Indeed PKU children show lower plasma cholesterol levels as compared to healthy children, particularly low density lipoprotein particles. Nevertheless both dietary habits and genetic predisposition may interact in keeping low blood lipid levels in PKU population [2]. However a lower antioxidant status and higher homocysteine levels have been reported in PKU, suggesting a possibly increased risk for thrombosis, atherosclerosis and stroke $[4,5]$.

Furthermore, even if PKU children are routinely longterm monitored for dietary intake some studies showed evidence for overweight in this population [6,7]. However more data on body composition in PKU individuals are needed. Further research should be necessary to better understand the nutritional quality of low-protein foods and Phe-free protein substitutes. This nutritional aspect

Department of Pediatrics, San Paolo Hospital, Department of Health Sciences, University of Milan, 20142, Italy

C 2014 Verduci et al: licensee BioMed Central Ltd. This is an Open Access article distributed under the terms of the Creative Commons Attribution License (http://creativecommons.org/licenses/by/4.0), which permits unrestricted use, distribution, and reproduction in any medium, provided the original work is properly cited. The Creative Commons Public Domain Dedication waiver (http:// creativecommons.org/publicdomain/zero/1.0/) applies to the data made available in this article, unless otherwise stated. is particularly interesting, in view of recent results about low-protein products: low-protein bread, pasta, flour and breakfast cereals appear to provide from 2 to $18 \%$ more energy than their protein-containing equivalent food [6] and some low-Phe pasta and crackers, commercially available, show an high glycemic index (data unpublished). Moreover an altered food behaviour, such as an irregular intake of higher fat food or low-protein foods, has been reported $[8,9]$. Few data are available on physical activity levels in PKU patients [8].

In conclusion given the growing population of adults with PKU, it could be important to investigate the noncommunicable diseases risk in this population to better optimize nutritional treatment strategies.

\section{Published: 11 August 2014}

\section{References}

1. Blau N, Van Spronsen F, Levy H: Phenylketonuria. Lancet 2010, 376:1417-1426. nutritional advances and challenges. Nutr Metab 2012, 9:7.

3. Giovannini M, Verduci E, Salvatici E, Fiori L, Riva E: Phenylketonuria: dietary and therapeutic challenges. J Inherit Metab Dis 2007, 30:145-152.

4. Feillet F, Agostoni C: Nutritional issues in treating phenylketonuria. J Inherit Metab Dis 2010, 33:659-664.

5. MacLoed E, Ney D: Nutritional management of Phenylketonuria. Ann Nestlè 2010, 68:58-69.

6. Rocha J, MacDonald A, Trefz F: Is overweight an issue in phenylketonuria? Mol Genet Metab 2013, 110(Suppl):S18-24.

7. Scaglioni S, Verduci E, Fiori L, Lammardo AM, Rossi S, Radaelli G, Riva E, Giovannini M: Body mass index rebound and overweight at 8 years of age in hyperphenylalaninaemic children. Acta Paediatr 2004, 93:1596-1600.

8. MacDonald A, Rocha JC, van Rijn M, Feillet F: Nutrition in phenylketonuria. Mol Genet Metab 2011, 104(Suppl):S10-8.

9. Robertson LV, McStravick N, Ripley S, Weetch E, Donald S, Adam S, Micciche A, Boocock S, MacDonald A: Body mass index in adult patients with diet-treated phenylketonuria. J Hum Nutr Diet 2012, 1(Suppl):1-6.

doi:10.1186/1824-7288-40-S1-A41

Cite this article as: Verduci et al:: Nutrition and inborn errors of metabolism: challenges in Phenylketonuria. Italian Journal of Pediatrics 2014 40(Suppl 1):A41.
2. Giovannini M, Verduci E, Salvatici E, Paci S, Riva E: Phenylketonuria:
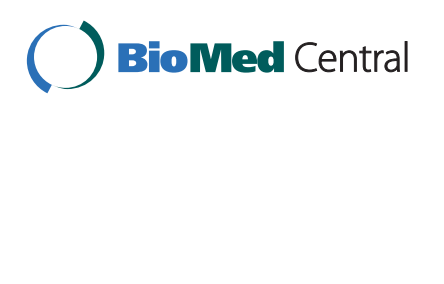